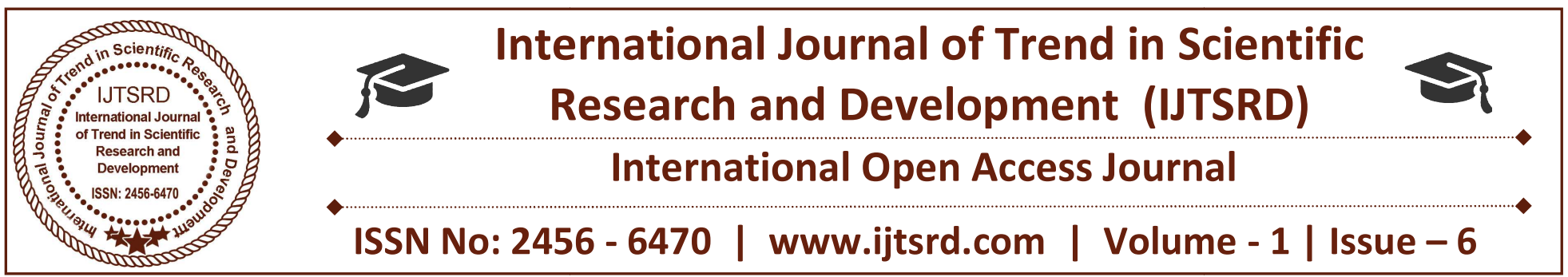

\title{
Vulnerability of Slums to Livelihood Security: A Case Study of 3 JJ Clusters, Delhi
}

\author{
Shweta Sharma \\ Assistant Professor, Department of Planning, School \\ of Planning and Architecture, Vijayawada
}

\author{
Akhil Chhibber \\ Master's Student pursuing Urban and Regional \\ Planning, Department of Planning, School of Planning \\ and Architecture, Vijayawada
}

\begin{abstract}
Vulnerability has been defined as the characteristics of a person or a group of persons i.e. in terms of their capacity to cope with, anticipate, resist and recover from the impacts of natural or man-made hazards or any external event. Vulnerability is also defined as the inability to withstand the effects of hostile environment. Hostile environment refers to livelihood security in this research. Concept of vulnerability is described within five categories of livelihood security, which are economic, social, education, food and health. The parameters for assessing the vulnerability of slums for different location are within the five categories of livelihood security that are economic security, social security, education security, food security and health security.
\end{abstract}

Keywords: Vulnerability, livelihood security, health security, social security, economic security, food security, education security

\section{Introduction}

Livelihood is a means of making a living. It incorporates people's abilities, assets, income and actions required to secure the requirements of life. A livelihood is sustainable when it enables people to cope with and recover from shocks and stresses (such as natural disasters and economic or social disturbances) and improve their well-being and that of upcoming generations without undermining the natural environment or resource base. Livelihood becomes vulnerable when it fails to cope with or recover from such stresses and shocks. Vulnerability of a slum can be assessed on countless scales like location of the slums and status of housing, availability and accessibility of basic services like water supply, drainage and toilets, nature of occupation/employment, access with social, physical and economic accessibility to health services, status of gender, education, social capital and existence of development organizations and activities.

\section{Research questions and Methodology}

To assess the level of vulnerability to livelihood security for different slum locations certain research questions need to be answered:

1. What are the parameters used to assess the vulnerability to livelihood security for slums?

2. Does the location of slums have any effect on livelihood security of slums?

3. Which location of slums is highly vulnerable to livelihood security?

4. What parameter of livelihood security is most important that affects vulnerability the most?

The research began with an extensive literature review on concepts related to vulnerability and livelihood security. The research gap identified was helpful in framing the aim of the study that is to assess the level of vulnerability to livelihood security for chosen slum clusters. The parameters were developed for assessing the vulnerability to livelihood security and vulnerability index was calculated with respect to the various kinds of livelihood security viz food, education, economic, health and social security and also with respect to the three chosen locations. 
The main tools used for analysis are Arc GIS 10.1, MS Excel and SPSS. The outcome of the research is a vulnerability index and a livelihood security matrix drawn with reference to different slum locations.

\section{Study area: Delhi}

The case area taken for this research is the capital city of India i.e. New Delhi (Figure 1). Haryana borders it on three sides and by Uttar Pradesh to the east.

\section{Figure 1: Delhi Location Map}

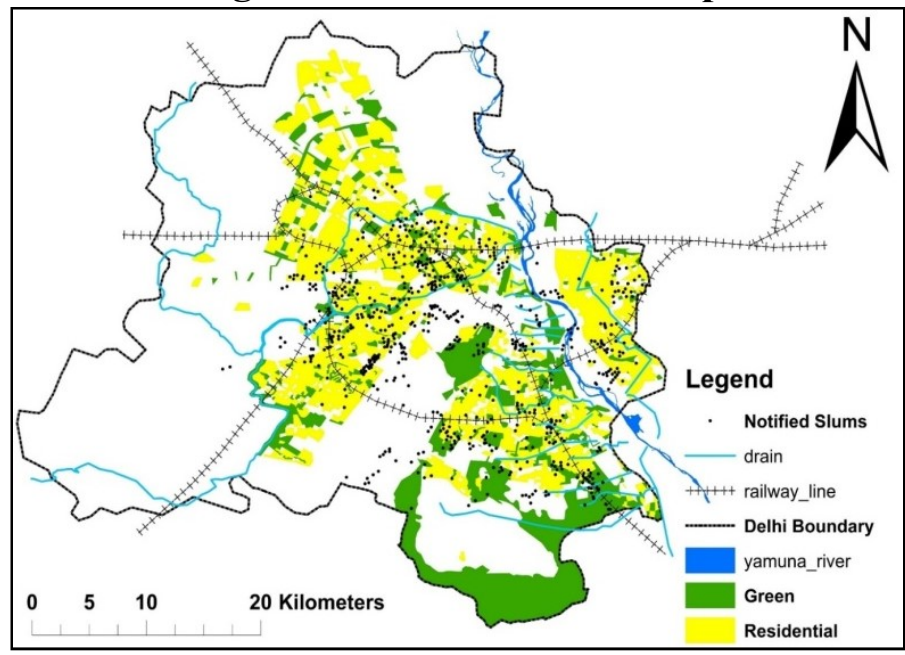

The case area for this research is JJ Cluster in New Delhi. Delhi, capital of India, is home to about 2 million persons living in slums and it is assessed that $45 \%$ of its population lives in unofficial colonies, JhughiJhompri (JJ) and urban villages.

Figure 2: Location of JJ Cluster in New Delhi

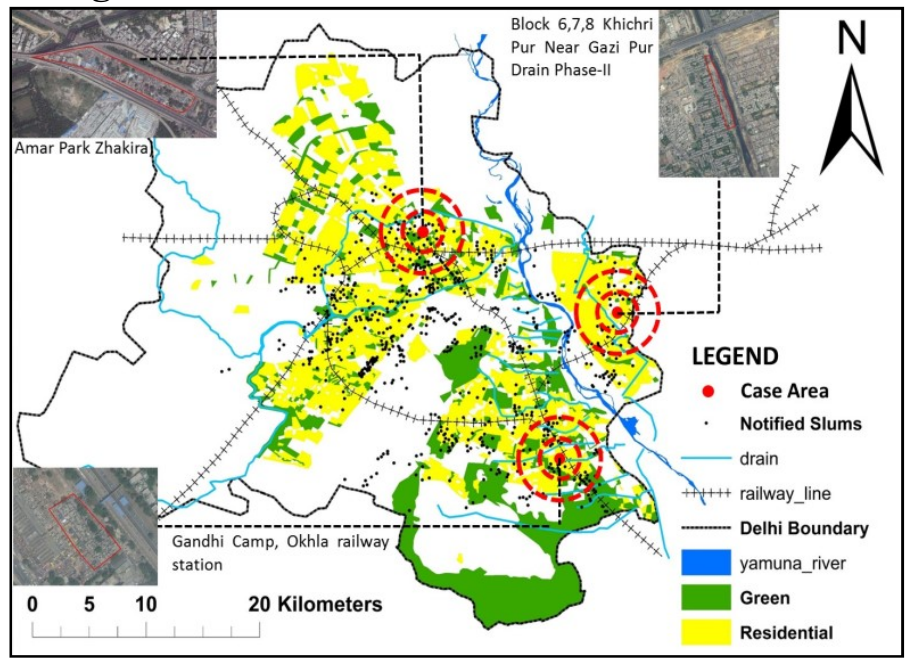

As per Census 2011, Delhi state had approximately 4.2 lakhs Jhuggi Households with a population of approximately 21.5 lakh. As per Municipal Corporation of Delhi(MCD) records there were in all 860 JJ clusters in Delhi during 2011 census. Considering location as a parameter to select the $\mathrm{JJ}$
Clusters in the study area, $27.64 \%$ of slums area near railway track, 27.73 percent of slums are near green area and $26.19 \%$ of slums are location near Naalah/drain. The remaining JJ clusters exist in other locations that comprise $18.44 \%$. The location of slums i.e. near railway track, near green area and near nallah together contributes a total of $81.56 \%$ of the total notified JJ clusters in Delhi. Hence the JJ clusters taken into consideration for research are near nallah (Ghazipur), near railway track (Okhla) and near green area. (Zakhira) The detailed location of the individual 3 slums is shows in figure 2 .

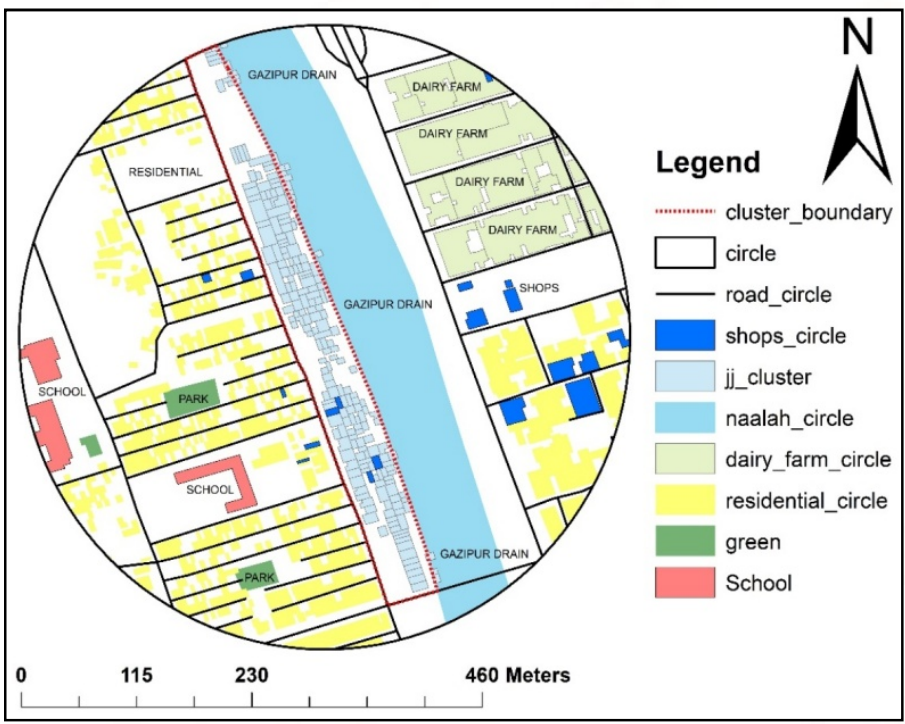

Figure 3: Land use of Ghazipur slum near nallah

Ghazipur Slum is in East Delhi Tehsil in East Delhi District of Delhi State, India. This Place is in the border of the East Delhi District and Gautam Buddha Nagar District.

\section{Figure 4: Land use of Okhla slum near railway} Track

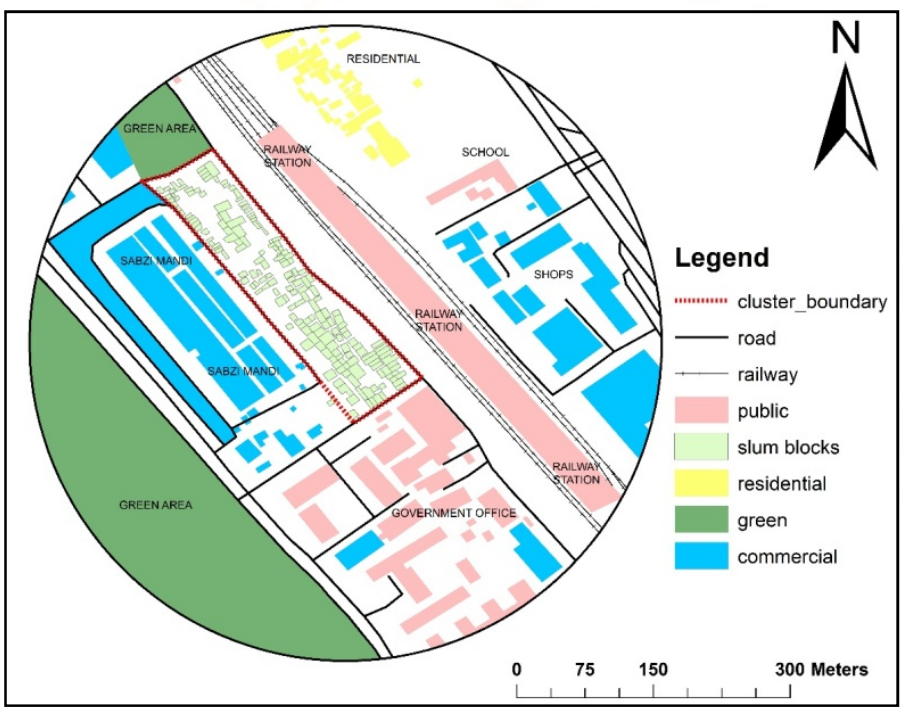


The slum is connected by road to NH 24. The slum has rail connectivity to AnandVihar railway station, AnandVihar metro station and AnandVihar old railway station. The detailed land use of the slum is depicted in figure 3. Okhla Slum is located in South Delhi district located at Delhi border. It is well connected by road and rail and is not far from the airport, as it is located in the centre of the National Capital Territory. Okhla is also connected to the Delhi Metro.

Figure 5: Land use of Zakhira slum near green area

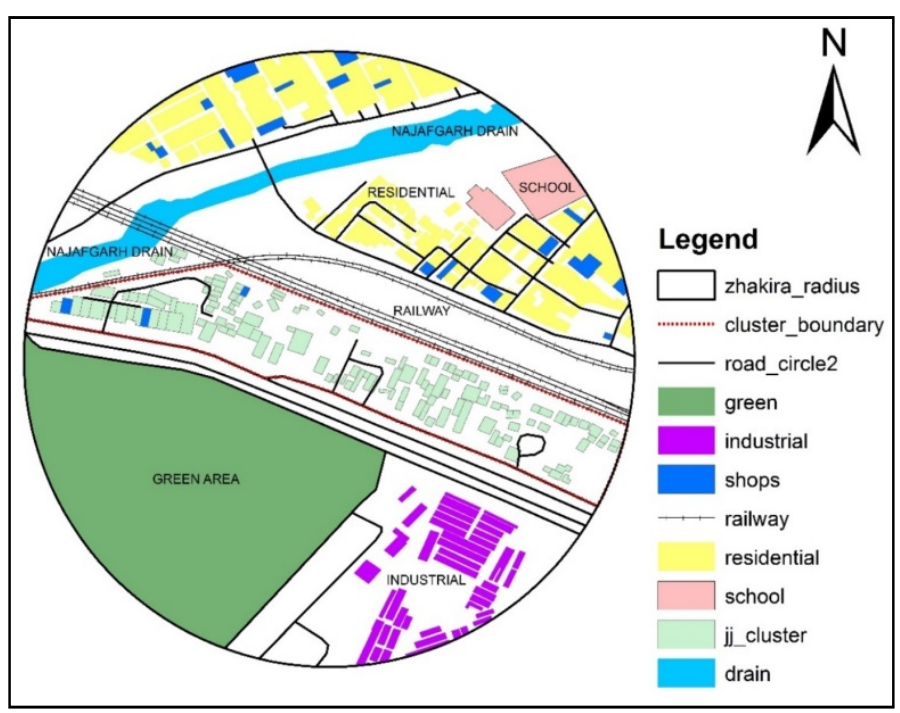

The land use of Okhla Slum is depicted in figure 4. Zhakira slum is located in the North West district of Delhi. The JJ Cluster is well connected through road and public transport. Further, two Delhi Metro stations namely Keshav Puram and Kanhiya Nagar located in its proximity enhances its connectivity. The land use of Zakhira slum is depicted in figure 5.

\section{Data}

Primary data was collected through household questionnaire survey key informant survey and also through observation survey. The main themes included in the questionnaire are the different components of livelihood security that are economic security, health security, education security, food security and social security. The data was collected at 2 levels. The data for health, education, economic, food and social scenario of the slum dwellers was collected at household level and data for the age, sex, education, occupation, income, education level, mode of transport and transportation cost was collected at individual level. The secondary data was collected from various government departments such as Delhi slum map that shows location of different slums clusters, list of notified slums and household size of JJ cluster i.e. with location and Slum Free City Plan of Action (SFCPoA) draft report from Delhi Urban Shelter Improvement Board (DUSIB). Households were selected randomly from the 3 slums. The size was determined using the Cochrane formula:

$$
X=\frac{t^{2} * P(1-P)}{M E^{2}}
$$

Where,

$\mathrm{X}=$ No. of Samples

$\mathrm{t}=$ Percentage of Confidence (90\%@1.64)

$\mathrm{ME}=$ Marginal Error (0.1)

$\mathrm{P}=$ Percentage of Population in the slum to the total slum population

\section{Analysis}

The vulnerability index includes 5 components namely economic security, health security, education security, food security and social security. Each component is comprised of several indicators or subcomponents. These were being developed based on a review of the literature on each major components and discussion with experts. The measurement of subcomponent is based on the quantitative and qualitative parameters i.e. based on literature. So, because each of the sub-components is being measured on a different scale i.e. quantitative as well as qualitative, it is important to standardize each of the subcomponents as an index. The method used for standardizing the sub-component is ranking of the sub-components that may be quantitative or qualitative based on existing literature and general understanding about the subject.

The values of the sub-components have been assigned rank from 1 to 3 i.e. 1 being the least vulnerable, 2 being moderately vulnerable and 3 being highly vulnerable. The ranking for the individual variable under economic security are income, female-headed households, household savings, access to work, travelling Cost, unnecessary expenditure, structure oh house and occupation. The ranking for the individual variables under health security are condition of toilet, water supply, drainage condition, availability of electricity, morbidity in the slum area, immunization and access to health facility. The ranking for the individual variable under education security is education level, male Literacy, female Literacy, adult male literacy (18+), adult female literacy (18+) and number of children in school. The ranking for the 
individual variable under food security are support, household size, female Children and widow. access/availability of food, number of food The scoring criterion has been explained in table 1 . convenient months, number of meals per day and expenditure on food. The ranking for the individual variables under social security are $\mathrm{CBO} / \mathrm{NGO}$ participation, access to $\mathrm{CBO} / \mathrm{NGO}$, household participation in planning process, level of social

Further the rank of the sub-component has been multiplied by the weightage being assigned to that particular sub-component based on expert opinion. Finally, the score of the individual sub-component have been identified i.e. based

\section{Table 1: Scoring Criterion}

\begin{tabular}{|c|c|c|c|c|c|}
\hline \multirow{2}{*}{ COMPONENTS } & \multirow{2}{*}{$\begin{array}{c}\text { SUB- } \\
\text { COMPONENTS }\end{array}$} & \multirow{2}{*}{$\begin{array}{l}\text { WEIGH } \\
\text { TAGE }\end{array}$} & \multicolumn{3}{|c|}{ VULNERABILITY } \\
\hline & & & LOW(1) & MEDIUM(2) & HIGH(3) \\
\hline \multirow{7}{*}{ HEALTH (7.61) } & Water & 9 & Available & $\begin{array}{l}\text { Less than } \\
\text { demand }\end{array}$ & No water \\
\hline & Toilet & 8.62 & Available & Common toilet & No Toilets \\
\hline & Drainage & 7.54 & Ground drain & Open drain & No drain \\
\hline & Electricity & 6.46 & Metered & $\begin{array}{l}\text { Pay to } \\
\text { landlord }\end{array}$ & No \\
\hline & Morbidity & 7.15 & None & $\begin{array}{c}\text { Better than } \\
\text { previous }\end{array}$ & High illness \\
\hline & Immunization & 6.92 & Regular & Irregular & None \\
\hline & Access to health & 7.69 & $<1 \mathrm{~km}$ & $2-3 \mathrm{~km}$ & $>3 \mathrm{~km}$ \\
\hline \multirow{8}{*}{$\begin{array}{c}\text { ECONOMIC } \\
(\mathbf{8 . 9 2 )}\end{array}$} & Female $\mathrm{HH}$ & 5.31 & Male HH & - & Female HH \\
\hline & $\begin{array}{l}\text { Distance to work } \\
\text { place }\end{array}$ & 7.23 & $<1 \mathrm{~km}$ & $2-3 \mathrm{~km}$ & $>3 \mathrm{~km}$ \\
\hline & $\begin{array}{l}\text { Unnecessary } \\
\text { Expenditure }\end{array}$ & 4.31 & None & - & Alcohol etc. \\
\hline & Structure of house & 5.77 & Pucca & Semi-Pucca & Kutcha \\
\hline & $\mathrm{HH}$ income & 8.92 & $>$ Rs 6000 & $\begin{array}{l}\text { Rs } 3000- \\
\quad 6000\end{array}$ & $<$ Rs 3000 \\
\hline & Family savings & 7.31 & YES & - & NO \\
\hline & Occupation & 8.31 & Job, Shop, trade & $\begin{array}{l}\text { Semi/Unskille } \\
\text { d }\end{array}$ & $\begin{array}{l}\text { Ragpicking, } \\
\text { recycling }\end{array}$ \\
\hline & Travel cost & 7.23 & $<$ Rs 50/None & Rs $50-100$ & $<$ Rs 100 \\
\hline EDUCATION & School children & 7.38 & Elementary & School and & Working/None \\
\hline
\end{tabular}


International Journal of Trend in Scientific Research and Development (IJTSRD) ISSN: 2456-6470

\begin{tabular}{|c|c|c|c|c|c|}
\hline \multirow[t]{6}{*}{ (7) } & & & Education & working & \\
\hline & Illiterate Male & 6.54 & $\begin{array}{l}\text { Elementary } \\
\text { Education }\end{array}$ & $\begin{array}{l}\text { Functional } \\
\text { Literacy }\end{array}$ & Illiterate \\
\hline & Illiterate Female & 6.77 & $\begin{array}{l}\text { Elementary } \\
\text { Education }\end{array}$ & $\begin{array}{l}\text { Functional } \\
\text { Literacy }\end{array}$ & Illiterate \\
\hline & $\begin{array}{l}\text { Adult male } \\
\text { literacy }\end{array}$ & 7.31 & $\begin{array}{l}\text { Elementary } \\
\text { Education }\end{array}$ & $\begin{array}{l}\text { Functional } \\
\text { Literacy }\end{array}$ & Illiterate \\
\hline & $\begin{array}{l}\text { Adult female } \\
\text { literacy }\end{array}$ & 7.69 & $\begin{array}{l}\text { Elementary } \\
\text { Education }\end{array}$ & $\begin{array}{l}\text { Functional } \\
\text { Literacy }\end{array}$ & Illiterate \\
\hline & $\begin{array}{l}\text { Access to } \\
\text { Education }\end{array}$ & 7.77 & $<1 \mathrm{~km}$ & $2-3 \mathrm{~km}$ & $>3 \mathrm{~km}$ \\
\hline \multirow{4}{*}{ FOOD (8.15) } & Meals per day & 8.08 & 3 & 2 & 1 \\
\hline & $\begin{array}{l}\text { Food Convenient } \\
\text { months }\end{array}$ & 6 & 12 months & 9 - 12 months & $<9$ months \\
\hline & Access to food & 9.38 & $<1 \mathrm{~km}$ & $2-3 \mathrm{~km}$ & $>3 \mathrm{~km}$ \\
\hline & $\begin{array}{l}\text { Expenditure on } \\
\text { food }\end{array}$ & 7.69 & Rs 1000 - 2000 & $\begin{array}{l}\text { Rs } 2000- \\
\quad 3000\end{array}$ & >Rs 3000 \\
\hline \multirow{7}{*}{ SOCIAL (7.61) } & $\begin{array}{l}\mathrm{CBO} / \mathrm{NGO} \\
\text { participation }\end{array}$ & 6.62 & YES & - & NO \\
\hline & $\begin{array}{c}\text { Access to } \\
\mathrm{CBO} / \mathrm{NGO}\end{array}$ & 6.69 & YES & - & NO \\
\hline & $\begin{array}{l}\text { Involvement in } \\
\text { planning }\end{array}$ & 8 & YES & - & $\mathrm{NO}$ \\
\hline & Social assistance & 7.92 & $\begin{array}{c}\text { Organized } \\
\text { sector/No need }\end{array}$ & $\begin{array}{l}\text { Landlords/ } \\
\text { Employers/ } \\
\text { Neighbours }\end{array}$ & $\begin{array}{c}\text { Unorganized } \\
\text { sector/Money } \\
\text { lenders }\end{array}$ \\
\hline & Widow & 5.77 & NO & - & YES \\
\hline & HH size & 7.08 & $<5$ & $5-9$ & $>9$ \\
\hline & Teenage girls & 6.38 & $\mathrm{NO}$ & - & YES \\
\hline
\end{tabular}

on the score formula. Getting a common score for each sub-component will thereby result in standardization of the sub-component i.e. based on ranking and weightage on a standardized scale. After each of the sub-components were being standardized, the components were averaged using the equation below to calculate the value of each major component including economic, health, food, education and social security.

$$
M_{s}=\frac{\sum_{i=1}^{n} \operatorname{index}_{S_{s} i}}{n}
$$

Where $\boldsymbol{M}_{\boldsymbol{s}}$ is one of the five major components for livelihood security of slums i.e. Economic, Health, Education, Food and Social Security. The Index represents the sub-component, indexed by $i$ that make up each major component and $\mathrm{n}$ is the number of subcomponent in each major component. Once values for 
each of the seven major components for a district were calculated, they were averaged using the below equation to obtain the slum level Vulnerability Index:

$$
V I_{s}=\frac{\sum_{i=1}^{5} W_{M_{i}} M_{s i}}{\sum_{i=1}^{5} W_{M_{i}}}
$$

which can also be expressed as:

$$
V I_{s}=\frac{W_{E} E_{s}+W_{H} H_{s}+W_{E} E_{s}+W_{F} F_{s}+W_{S} S_{s}}{W_{E}+W_{H}+W_{E}+W_{F}+W_{S}}
$$

Where $\boldsymbol{V} \boldsymbol{I}_{\boldsymbol{s}}$, is the Vulnerability Index for slum s, equals the weighted average of the five major components. The weight to each sub-component has been assigned based on expert opinion. Low vulnerability index ranges from $0.01-0.35$, medium vulnerability index ranges from $0.35-0.70$ and high vulnerability index ranges from $0.70-0.10$.

\section{Results and Discussion}

\subsection{Vulnerability based on Securities}

\subsubsection{Economic Security:}

Based on the economic security index i.e. vulnerability in terms of economic security (figure 6), it can be inferred that the major parameters that increase the level of vulnerability are average family savings which are directly linked to the household income thereby leading to vulnerability with regard to structure of house, occupation and access to workplace. The sub-components such as unnecessary expenditure and female-headed households are not vulnerable and are secure in case of economic security. The major issue identified is that $25 \%$ of the total population does not perform any activity for source of occupation. This population majorly includes old aged people, housewife, widow and a few young members. As a result there is no family savings in the households. Even the family who do have some savings, it is less than Rs. 2000 per month. The majority of income being earned by the households is spent on their source of living i.e. food.

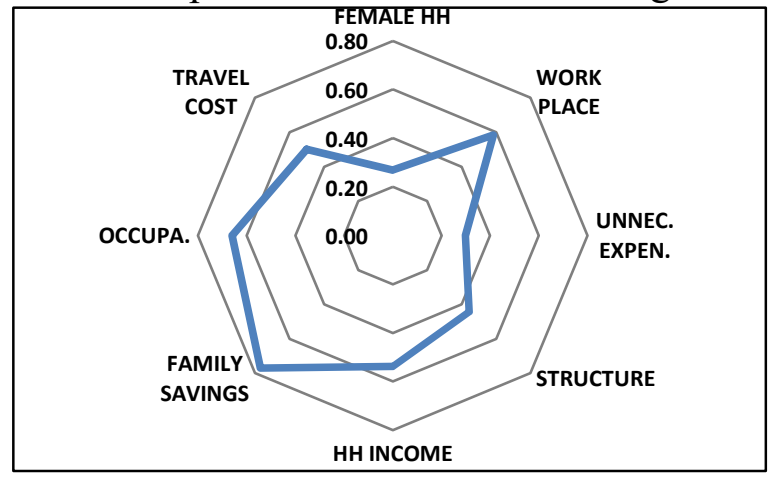

Figure 6: Vulnerability to Economic Security based on sub-components

\subsubsection{Health Security:}

Based on the vulnerability index to health security, it can be inferred that the major parameters that increase the level of vulnerability in terms of health security are availability of individual or community toilets, dependency on open area for toilet, lack of availability of water supply pipelines, no provision for drainage and a lack of immunization (figure 7).

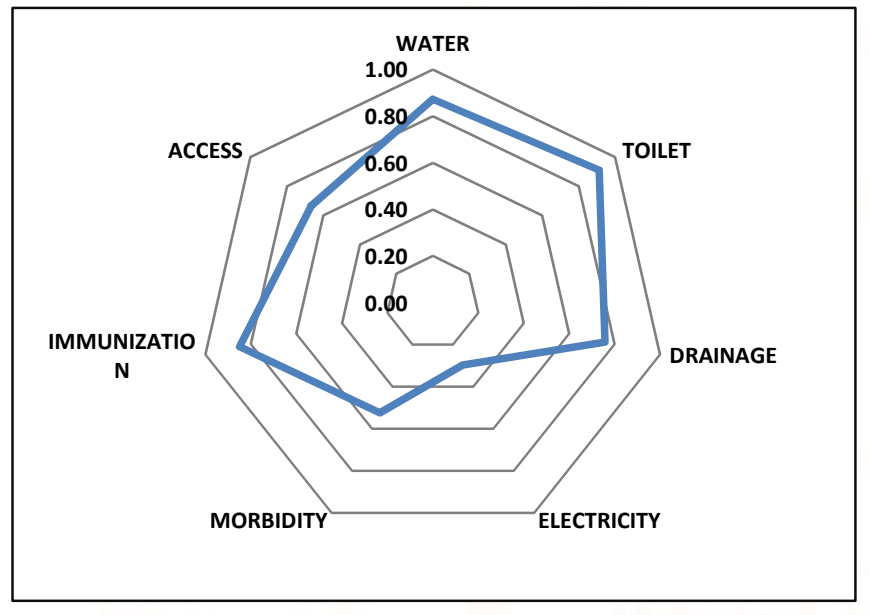

\section{Figure 7: Vulnerability to Health Security based on sub-components}

6.1.3 The other sub-components including electricity, morbidity and access to health care facilities have low level of vulnerability. In case of slum areas where a high rate of illness has been considered, no proper immunization service has been observed in the slum area that is an important factor that increases the level of vulnerability to health security. Lack of proper water supply i.e. in terms of quality and quantity and dependency on open ground for toilets. Open/No drain in the study area is one of the reasons that leads to a high level of illness among the slum households which thereby leads to an increase in level of vulnerability in terms of health security.

6.1.4 Education Security: In terms of educations security, there is proper provision of education facility with a low level of vulnerability in terms of access to education facilities (figure 8). The major issue is illiteracy among adults. The children in the study area are found to be less vulnerable as compared to adults when education security is being considered. 
Figure 8: Vulnerability to Education Security based on sub-components

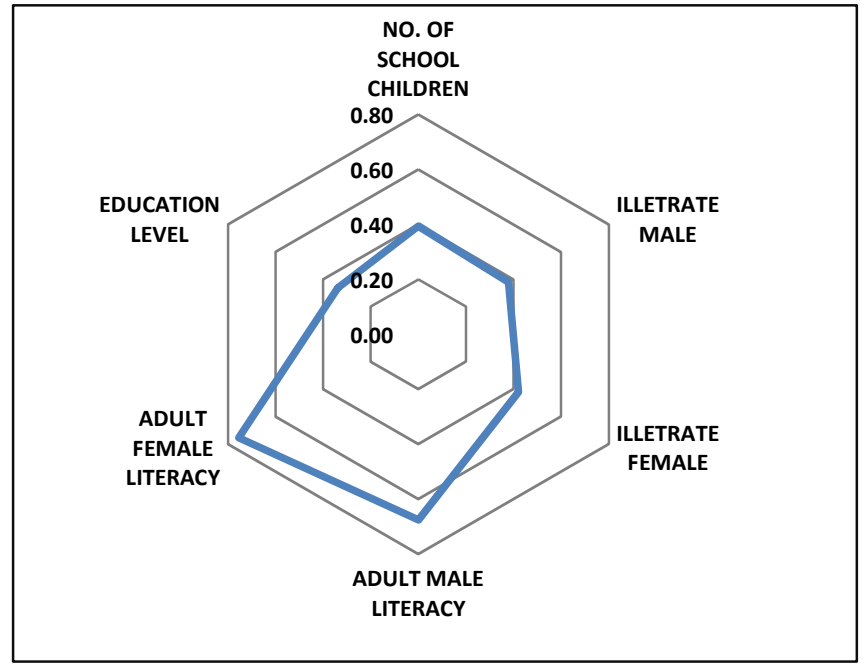

6.1.5 Food Security: There is no problem in terms of availability and accessibility to food (figure 9). The major issue is the expenditure on food. The majority of income of the households is spent on food.

Figure 9: Vulnerability to Food Security based on sub-components

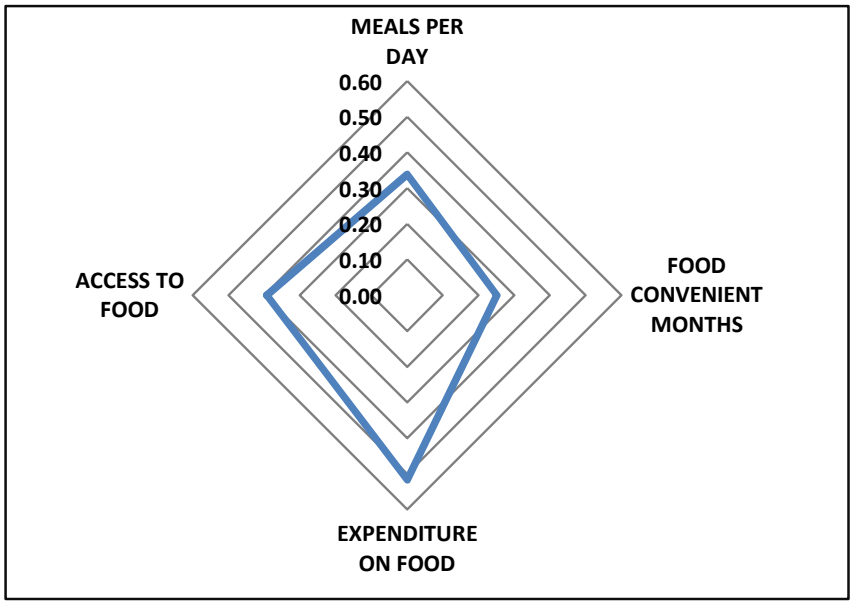

\subsubsection{Social Security:}

After health security, social security is the component that affects livelihood security the most. The major sub-components that increase the level of social security are participation by the $\mathrm{CBO} / \mathrm{NGO}$, access to $\mathrm{CBO} / \mathrm{NGO}$, involvement in planning process and social assistance (figure 10). Further other subcomponents including girl child in teenage, household size and availability of widow in households have been observed to have a low level of vulnerability when social security is considered. The issues are that no $\mathrm{NGO} / \mathrm{CBO}$ participation is there for the betterment of slums. Further social assistance is an issue, as slum dwellers have to depend on third party loan providers i.e. at an interest rate of $5-10 \%$ that increases the rate of vulnerability of slum households in terms of social security.

\section{Figure 10: Vulnerability to Social Security based} on sub-components

\subsection{Vulnerability based on Location}

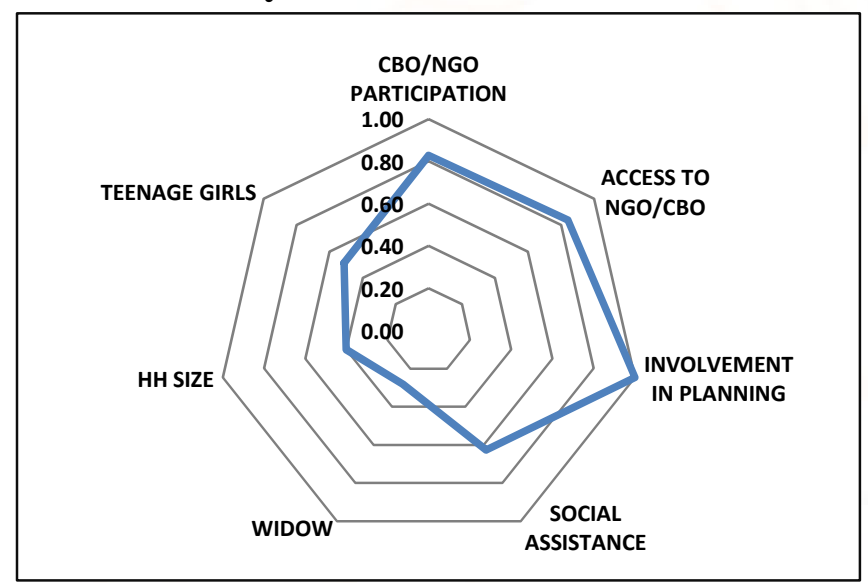

6.2.1 Economic Security: Taking location as a parameter to assess the level of vulnerability, Gazipur is having the highest level of vulnerability in terms of economic security followed by Okhla and Zhakira (figure 11).

Figure 11: Vulnerability to Economic Security based on location

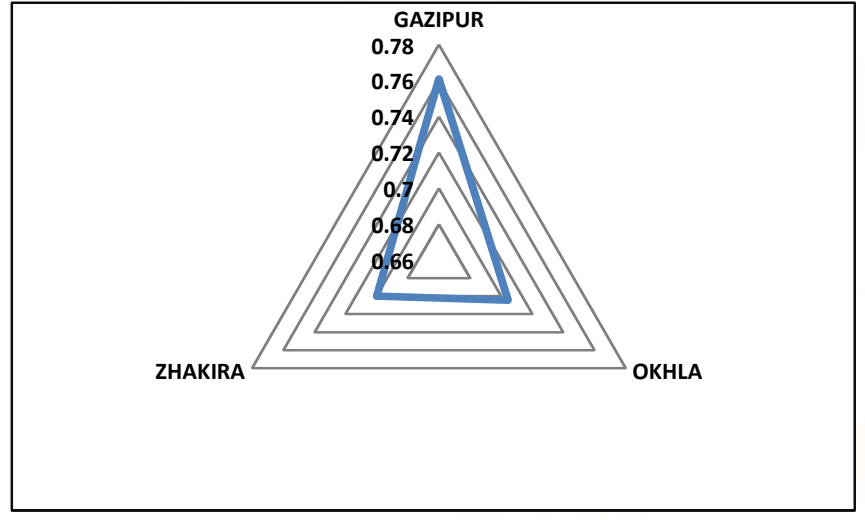

6.2.2 Health Security: In case of vulnerability to health security, Gazipur is maximum affected because of its location along the drain followed by Zhakira and Okhla (figure 12). Gazipur also faced a high rate of illness among slum dwellers which thereby increases the level of vulnerability in term of livelihood security. 
6.2.3 Education Security: In case of education security, Zhakira is highly vulnerable i.e. because of more number of illiterates as compared to other locations (figure 13). Zhakira is followed by Okhla leading to Gazipur having the least level of vulnerability in terms of education security.

Figure 12: Vulnerability to Health Security based on location

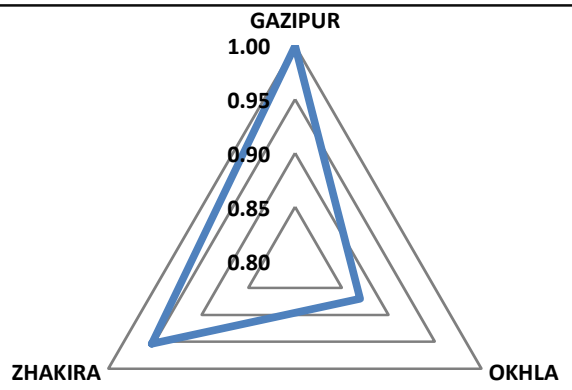

Figure 13: Vulnerability to Education Security based on location

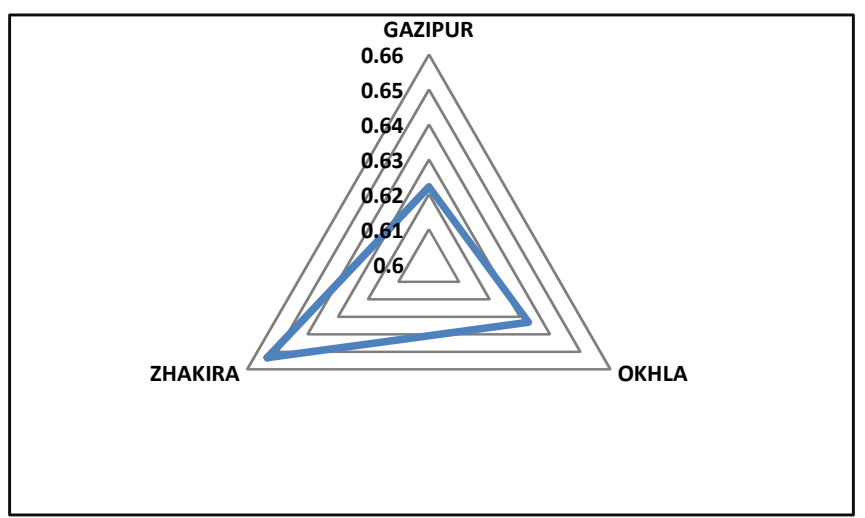

6.2.4 Food Security: Okhla although located along sabzimandi is highly vulnerable to food security as compared to other locations (figure 14). Reasons are low income, household savings and majority of spending on livelihood. Overall food security is less vulnerable in the 3 slum locations.
Figure 14: Vulnerability to Food Security based on location

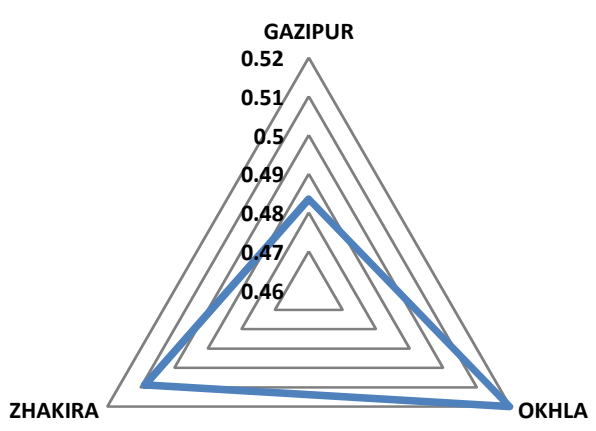

6.2.5 Social Security: Considering social security as a parameter to assess the level of vulnerability in the 3 different locations, Okhla is highly vulnerable to social security followed by Gazipur and Zhakira (figure 15). The reason for increase in level of vulnerability in terms of social security is because of the dependency on third party loan providers, lack of $\mathrm{NGO} / \mathrm{CBO}$ participation and lack of involvement in planning process.

Figure 15: Vulnerability to Social Security based on location

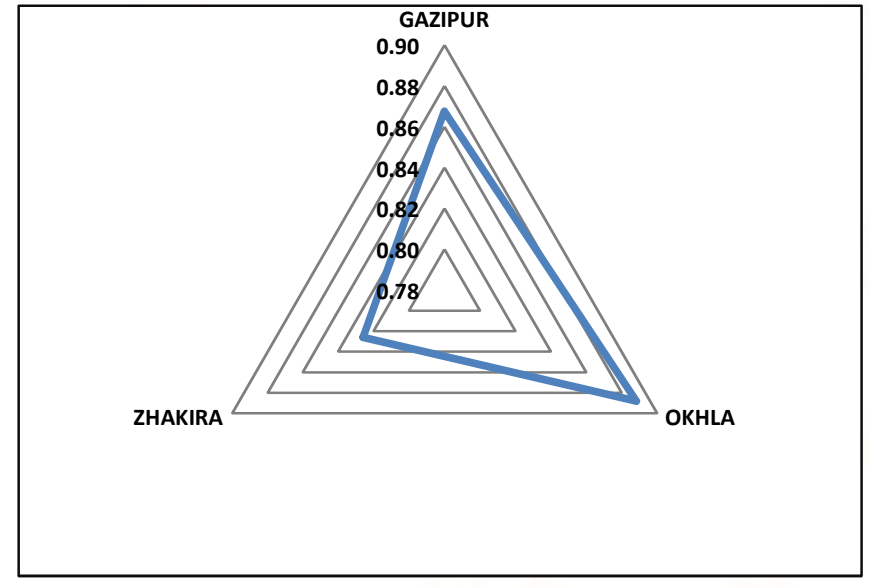

\subsection{Composite Vulnerability Index based on Securities}

The radar diagram above shows the level of vulnerability in terms of livelihood security in the study area. As per the radar diagram i.e. the livelihood vulnerability based on composite index, health security is highly vulnerable in terms of livelihood security in the study area followed by social and economic security (figure 16). Education and food security are moderately vulnerable and are considered 
secure when health, social and economic vulnerability are being considered.

Figure 16: Composite Vulnerability to five securities

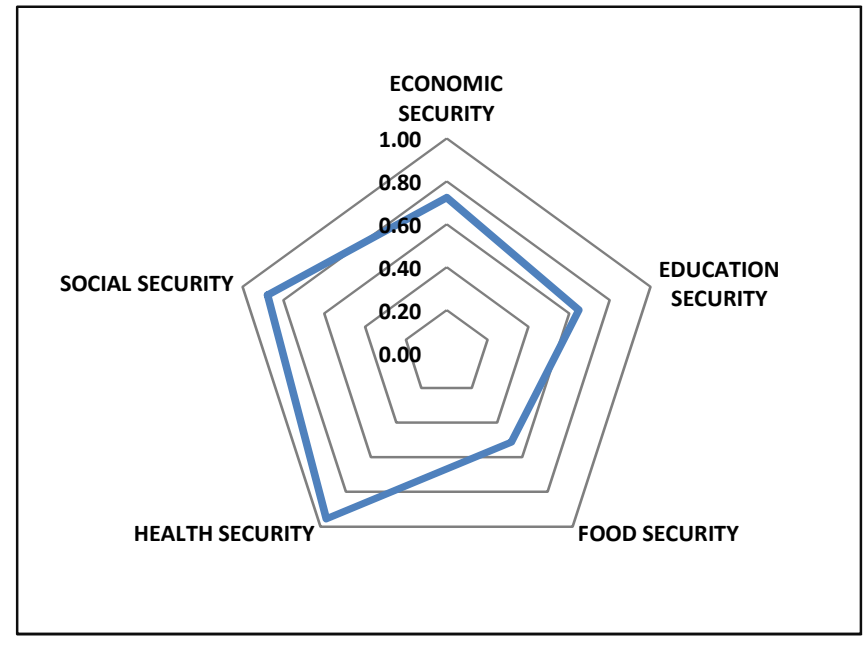

Figure 17: Composite Vulnerability with respect to location

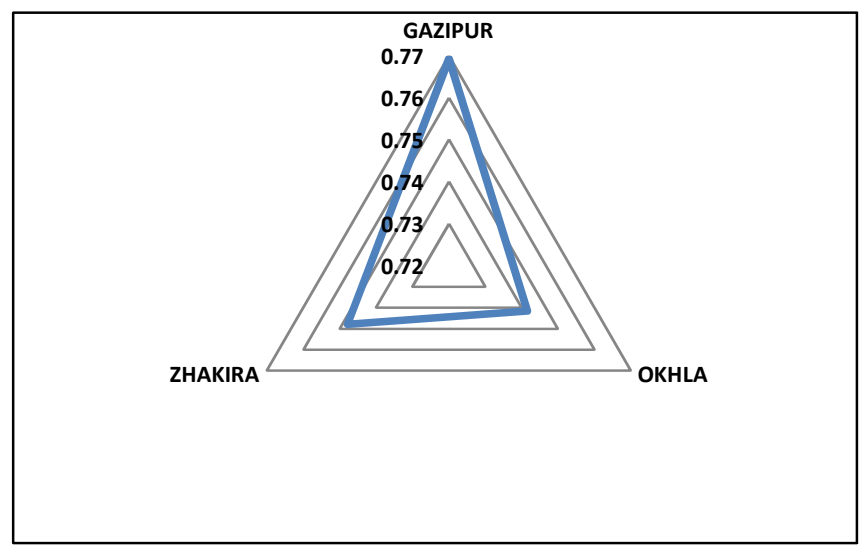

\subsection{Composite Vulnerability Index based on Location}

Based on location, Gazipur is having the highest level of vulnerability followed by Zhakira and Okhla i.e. in terms of livelihood security (figure 17).

\subsection{Livelihood Security, locationand Vulnerability}

The radar diagram (figure 18) depicts the different components of livelihood security and how they contribute to increase or decrease in the level of vulnerability in terms of livelihood security. The maximum affected is Gazipur in terms of health security, which is because of its location along the drain. Further the economic security is also highly vulnerable in Gazipur. The least level of vulnerability has been observed in food security i.e. in Zhakira. The reason for this is availability and accessibility of food. This is due to less expenditure on food and the households having savings. Considering all the components of the livelihood security, food and education security are the least vulnerable and economic, health and social security are highly vulnerable.

Figure 18: Livelihood Security, location and Vulnerability

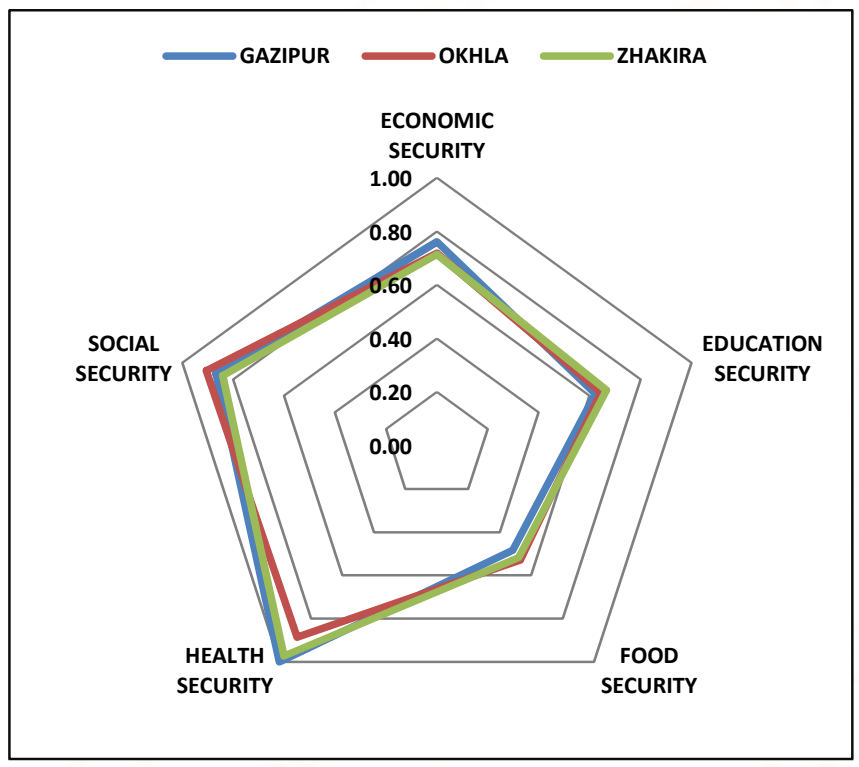

\subsection{Major Issues}

The level of vulnerability in terms of social security is highest in Okhla. The reason for this is more dependency on third party loan providers for social assistance to the slum dwellers. Gazipur is the location that is highly vulnerable in terms of livelihood security, which is because of its location. The major issues identified with respect to health security are lack of availability of water supply i.e. in terms of quality and quantity, lack of availability of toilets, dependency on open land for toilet, no provision of drain network for the slum dwellers i.e. open/no drain and no immunization service in the areas which are vulnerable to health security. In terms of education security the major issue is the low level of literacy rate of adults, both males and females. High rate of expenditure on food is the major problem that makes the food security highly vulnerable. Lack of $\mathrm{CBO} / \mathrm{NGO}$ participation, no involvement of slum dwellers $n$ planning process and dependency of slum dwellers on money lenders for social assistance are some of the factors deepening the vulnerability towards social security of slum dwellers. Economic security is vulnerable due to nil family savings or little family savings accounting for less than Rs. 2000 
per month and the informal employment of slum dwellers as street vendors or construction workers.

\section{CONCLUSION}

As a result of this research, it was identified that health security affects livelihood security the most, followed by social and economic security. The study along 3 different slums locations helps us identify the slum cluster located along environmentally sensitive zone i.e. along Naalah/drain is highly vulnerable to livelihood security when compared with other slum location. Gazipur slum i.e. the case area located along drain was highly vulnerable to livelihood security in the 3 slum locations. It is necessary to propose facilities in terms of infrastructure, social, economic etc. for the slum dwellers so as to make their livelihood secure. Education and food security were found to be least vulnerable in comparison to health, social and economic vulnerability. All the three slums need intervention in terms of provision of infrastructure. Since Gazipur is located near environmentally sensitive zone and is also observed to be highly vulnerable so it needs to be relocated. Considering Zhakira where housing structure has been observed to be pucca, slum infrastructure upgradation can be an option. Similarly in case of Okhla, housing up-gradation which includes upgradation of kutcha/semi-pucca structures into pucca and thereby provision of basic infrastructure components including toilet, water supply, drainage etc. can be thought of as one of the solutions to lessen the overall vulnerability of the slum. Also social assistance programs need to be initiated for elder population, widows along with provision of food at low cost.

This research will be helpful for further researchers, municipalities, development authorities etc. and work as a tool/index so as to assess the level of vulnerability to livelihood security of slums. As this research was limited to $3 \mathrm{JJ}$ clusters, future research can be done for city/state level vulnerability assessment. Future researchers can also amend the index by adding/deleting sub-components based on the study area and issues of the beneficiaries.

\section{REFERENCES}

1) CEPT University (2014). Slum Free City Action Plan Under Rajiv Awas Yojana: Ahmedabad Ahmedabad: Ahmedabad Municipal Corporation.

2) Delhi Development Authority (2021). Master Plan for Delhi. Delhi: Delhi Development Authority.
3) Department of Statistics (2015). Urban SLums in Delhi. Delhi: NSSO.

4) Dimanin, P. (2012). Exploring livelihoods of the urban poor in Uganda: An institutional, community and household contexual analysis. Kampala, Uganda: ACF International.

5) Frigerio, M. D. (2016). Mapping social vulnerability to natural hazards in Italy: A suitable tool for risk mitigation strategies. Italy: Elsevier.

6) IL \& FS Ecosmart Limited, N. D. (2006). City Development Plan Delhi. Delhi: Department of Urban Development, Government of Delhi.

7) Ivan Frigerio, S. V. (2016). A GIS-based approach to identify the spatial variability of social vulnerability to seismic hazard in Italy. Italy: Elsevier Science.

8) Jankowska, M. (2007). Continuums of Vulnerability in the Slums of Accra, Ghana. Accra, Ghana.

9) Jean-Yves Gerlitz, M. M. (2016). The Multidimensional Livelihood Vulnerability Indexan instrument to measure livelihood vulnerability to change in the Hindu Kush Himalayas. Hindu Kush Himayalas: Tailor and Francis.

10) Micah B. Hahn, A. M. (2009). The Livelihood Vulnerability Index: A pragmatic approach to assessing risks from climate variability and change-A case study in Mozambique. Mozambique: Elsevier Ltd.

11) MOHAPATRA, S. (2012). Assessing Differential Health Vulnerability of the Slums in Chandigarh, India. Chandigarh: Internationales Asienforum.

12) Nair, P. K. (2005). Vulnerability among slum dwellers in Lucknow, India: Implications of Urban Livelihood Security. Lucknow: International Development Planning Review.

13) Nair, P. K. (2014). Livelihood vulnerability assessment to climate variability and change using fuzzy cognitive mapping approach. Bhilwara: Springer.

14) Rahman, S. A. (2016). Investigating Multiple Domains of Household Livelihood Security: Insights from Urban Slums in Bangladesh. Bangladesh: Taylor \& Francis.

15) Rahman, N. A. (2016). Livelihood of Slumdwellers: Findings from Baseline Survey of Ultra Poor Programme. Bangladesh: BRAC Research and Evaluation Division.

16) Reed, M. Combining analytical frameworks to assess livelihood vulnerability to climate change and analyse adaptation options. PMC. 
17) Seth, S. B. (2016). A Comparative Study of Living Conditions in Slums of Three Metro Cities in India. Kolkatta, Mumbai and Delhi: Centre For Development Economics, Delhi.

18) Singh, P. (2009). Sheltering Delhi's Slums . Delhi: Centre for Civil Society.

19) Taneja, S. (2005). Health Vulnerability assessment of slums - a tool for better planning of health programs in urban areas. United States Agency for International Development.

20) Thinda, T. K. (2009). Community-Based Hazard and Vulnerability Assessment: A case study in Lusaka Informal Settlement, City of Tshwane. Tshwane: Centre for Disaster Risk Management Education and Training for Africa .

21) Zeynep Haki, Z. A. (2004). Assessment of Social Vulnerability Using Geographic Information Systems: Pendik, Istanbul Case Study. Istanbul: AGILE. 